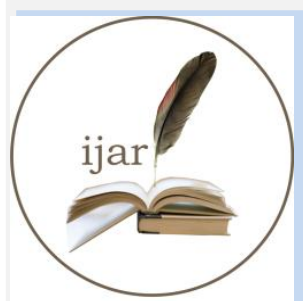

ISSN NO. $2320-5407$
Journal Homepage: $-\underline{w w}$.journalijar.com
INTERNATIONAL JOURNAL OF
ADVANCED RESEARCH (IJAR)

Article DOI: $10.21474 / \mathrm{IJAR01/1327}$

DOI URL: http://dx.doi.org/10.21474/IJAR01/1327

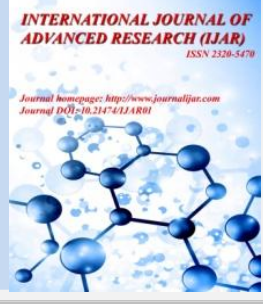

RESEARCH ARTICLE

\title{
USE OF CORRELATION AND REGRESSION ANALYSIS IN ESTIMATING RELATIVE IMPORTANCE OF FIBER PROPERTIES AFFECTING YARN HAIRINESS IN SOME EGYPTIAN COTTON GENOTYPES.
}

Hager M. A ${ }^{1}$ and A. A. Hassan ${ }^{2}$.

1. Agronomy Dept., Fac. of Agriculture, Al-Azhar Univ., Cairo, Egypt.

2. Cotton Research Institute, Agric. Res. Cent., Giza, Egypt.

\section{Manuscript Info}

Manuscript History

Received: 19 June 2016

Final Accepted: 26 July 2016

Published: August 2016

Key words:-

Cotton - Fiber properties - Yarn hairiness - Correlation - Stepwise regression

\section{Abstract}

Yarn hairiness can be desirable or undesirable, depending on the application for which the yarn is being used. Hairy yarns provide good heat retention and a softer hand (feel) for finished fabrics, and except for a few special cases, when there is an excessive degree of hairiness, it may be an undesirable property in yarn and probably cause serious problems in both yarn production and in subsequent textile processes. This search was carried out to investigate relative contributions of the most important fiber properties i.e. fiber length (upper half mean) (m.m), fiber strength (g/tex), micronaire reading, short fiber content $(\%)$, elongation $(\%)$ and uniformity index $(\%)$ which correlated with yarn hairiness using four Egyptian cotton genotypes namely; Giza 92, Giza 88, Giza 93 and G 84 (G70 x 51B) s 62 spun using combed ring and combed compact systems at count $\mathrm{Ne} 80$ and 100's carded yarns with 4.3 twist multiplier. The results indicated that yarns manufactured by the combed ring spinning frame are characterized by higher hairiness mean values in all studied cotton genotypes compared to those resulted of combed compact frame. Positive and highly significant association was observed between yarn hairiness and short fiber content while the associations between yarn hairiness and the rest fiber properties (fiber length (UHM), fiber strength (g/tex), micronaire, Elongation (\%) and uniformity index (\%)) were negative and significant or highly significant for all tested Egyptian cotton genotypes under the two spinning systems. The results of the full model regression and stepwise multiple linear regression differed according to the tested cotton genotype and also each of the applying spinning system and counts $(\mathrm{Ne})$ carded used. Generally, all regression models were significant and explained large part of the variation of yarn hairiness expressed as high values of $\mathrm{R}^{\mathbf{2}}$ and near values of the corresponding adjusted $\mathrm{R}^{2}$ indicating the validity and goodness of fit for these models. 


\section{Introduction:-}

Hairiness of staple yarns is due to the protrusion of fiber ends and loops from the yarn core. Yarn hairiness is a quite complex parameter of yarn quality that is affected by various parameters (fiber quality and the mechanical processing). It can be defined as the total number or total length of the fibers which leave from the unit yarn's surface, it is formed by surface fiber edges which leave the yarn center and spoil its appearance, the downside to yarn hairiness is that hairs tend to increase the amount of lint generated in processing and can affect processing at warping, slashing, weaving, and knitting by contaminating the process with loose lint (Altaş and Kadoğlu, 2006).

Hequet (1999) used upland cotton and focused on short fiber and length distribution how they affect ring spun yarns regularity. He found that yarn hairiness appears to be highly related to the fiber length distribution and the shortest fibers apparently tend to cause hairy protrusions from the ring spun yarns.

The percentages of both the shortest and the longest fibers have an important impact on yarn quality, the shortest fibers increase hairiness and the longest fibers decrease hairiness. Short fibers shorter than $1 / 4$ inch are important contributors toward increased yarn hairiness. The fibers longer than two inches which measure very long are important contributors toward decreased yarn hairiness. The shortest and the longest fibers are highly correlated with the hairiness for all the types of yarns. (Hequet and Ethridge, 2000).

The most important feature in obtaining high-quality yarns is the quality of raw material because the raw material costs constitute over 50\% of the unit cost of cotton yarn, and the yarn properties have changed with regard to raw material properties.

One of the most important fiber parameters that affect hairiness is the amount of trash, and yarn count during spinning processes where they are important parameters that affect the physical properties of yarns such as hairiness. (Karapinar and Erdem, 2003).

Yarn hairiness, in ring spinning process is greatly influenced by various fiber properties, among which the most commonly cited are length (length distribution) and fineness. (Krifa and Ethridge, 2006).

The acceptable spinning performance will differ by the raw fiber properties and by the technology for transforming these fibers into yarn, and both factors depending on the technology used. Krifa and Ethridge (2003) found that 50 $\mathrm{Ne}$ compact spinning carded yarn having-on the conventional frame- significantly yarn hairiness levels lower for a great majority of the compact spun yarns.

Compact or condensed spinning is a new concept of yarn forming. It represents a fundamental modification of the conventional ring-spinning system that aims at producing a better surface integrity of spun yarns that can largely be determined by yarn hairiness. The idea stems from the necessity of controlling the dimensions of the spinning triangle to reduce yarn hairiness (EI Mogahzy, 2000). 


\section{Conventional (combed) spinning triangle}

\section{combed compact spinning triangle}

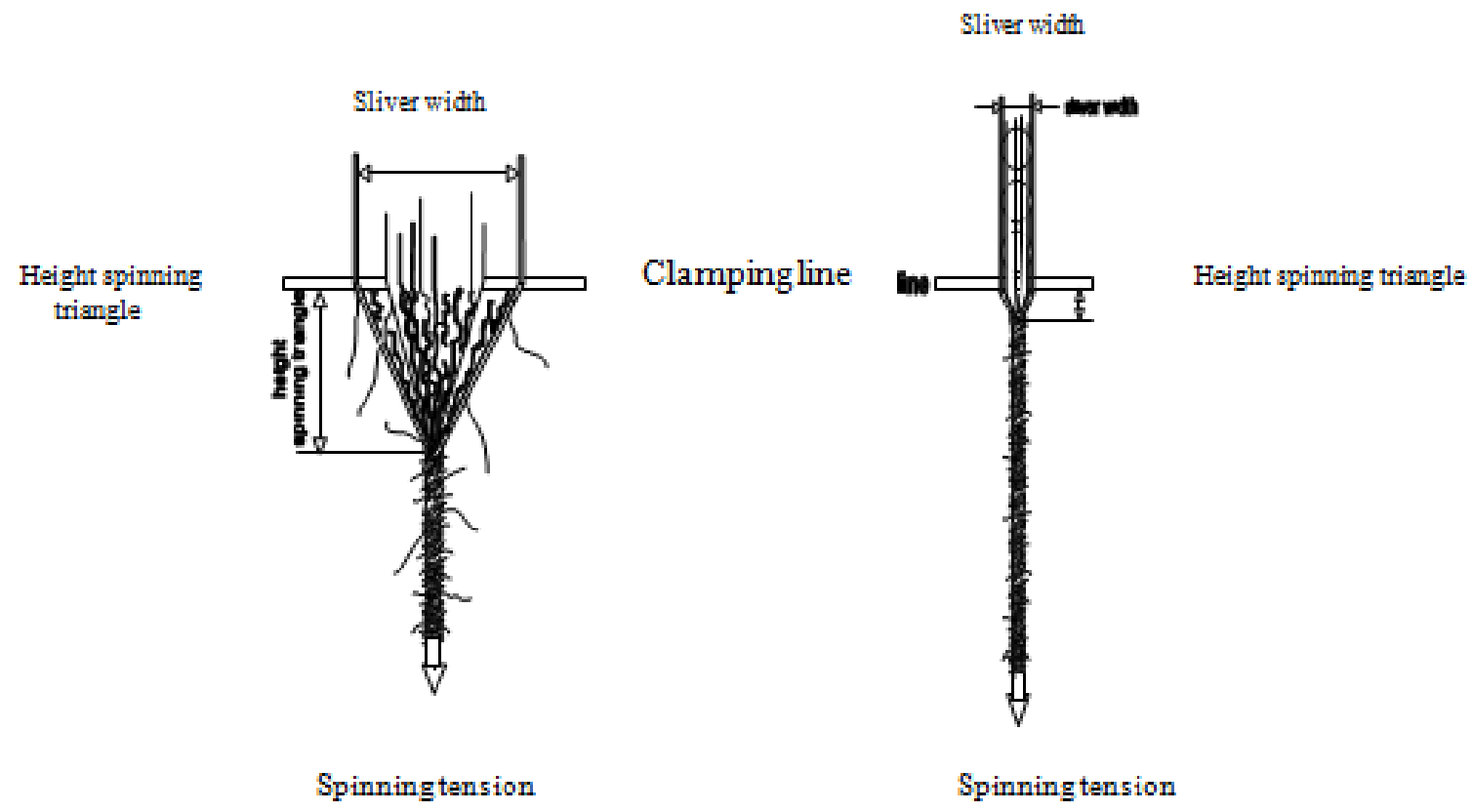

Fig. 1:- Comparison between conventional (combed) spinning triangle and combed compact spinning triangle

\section{Yarn Formation:-}

Artzt (2000) presented a figure of yarn formation (Fig. 1) shows how the compact sliver is twisted in a very small spinning triangle, thereby eliminating peripheral fibers. He added that, compact spinning produces yarns which represent a superior ring yarn because compact spinning forms fibers into a narrow sliver by drafting in a virtually tension-free process within a compacting zone to produce a novel yarns better strength with reduced hairiness therefore compact yarn provides a completely new approach to the problem of hairiness with carded yarn.

\section{Materials and methods:-}

The materials used in the present study included four Egyptian cotton genotypes namely; Giza92, Giza 88, Giza 93 and G84 (G70 x 51B) s62 following the Extra- Long Staple category according to the local practice in Egypt. The cotton samples of previously mentioned genotypes were taken from 2013 season and testing for hairiness during 2015 season.

All fiber and yarn tests were carried out at the laboratories of the Cotton Research Institute, Giza, Minister of Agriculture, Egypt under controlled atmospheric conditions of $20 \pm 1.1 \mathrm{C}^{\circ}$ temperature and $65 \pm 2 \%$ relative humidity.

For each cotton genotype separately, mean values were calculated from 12 repetitions to estimate the correlation coefficients and to apply multiple linear regression and stepwise multiple linear regression analysis according to regression equation of the following form: $Y=\beta_{o}+\beta_{1} X_{1}+\beta_{2} X_{2}+\ldots+\beta_{\rho} X_{p}$ Where $Y$ is the dependent variable "yarn hairiness index", $\beta_{\mathrm{o}}$ is the constant, $\mathrm{X}_{1}, \mathrm{X}_{2} \ldots$ to $\mathrm{X}_{\mathrm{p}}$ are the independent variables " fiber length (UHM) $\left(\mathrm{x}_{1}\right)$, fiber strength $(\mathrm{g} / \mathrm{tex})\left(\mathrm{x}_{2}\right)$, micronaire $\left(\mathrm{x}_{3}\right)$, short fiber content $(\%)\left(\mathrm{x}_{4}\right)$, Elongation $(\%)\left(\mathrm{x}_{5}\right)$ and uniformity index $(\%)$ $\left(\mathrm{x}_{6}\right)$ " and $\beta_{1}, \beta_{2}$...to $\beta_{\rho}$ are the partial regression coefficients as described by Draper and Smith (1966). The results would help the spinners in evaluating the relative contribution of the aforementioned fiber properties $\left(\mathrm{x}_{1}, \mathrm{x}_{2}, \ldots, \mathrm{x}_{6}\right)$ as explanatory variables on yarn hairiness index adependent variable. 
Fiber properties were tested and recorded according to the following methods and procedures:

1. Spinlap 900 B (HVI) Instrument System was used according to ASTM (D- 4603-86) to determine Upper Half Mean Length (UHM) by mm., fiber strength (g/tex), short fiber content (\%), elongation (\%) and uniformity index.

2. Determining Micronaire by using Micromat Tester (SDL 089) (1994).

3. 3- Fibers of the four Egyptian cotton Genotypes (Giza92, Giza 88, Giza 93 and G84 (G70 x 51B) s62) were spun to produce combed ring and combed compact yarns at twist multiplier 4.3.with two counts (Ne) according to the following: Ring yarns were processed to combed yarns Ne 80 and 100. Combed Compact yarns were also processed to combed yarns at the same counts (processed to combed yarns Ne 80's and 100's noil 18\%).

4. Yarn hairiness was measured by a computerized type of Uster Evenness Tester (Uster Tester 3) (UT3) according to the standard methods of testing textile materials (ASTM -D-1425-98) (1998), for evenness and hairiness where hairiness parameter: $\mathrm{H}$ is expressed as the total hair length per yarn centimeter, and hence unit less, (H -UT3 hairiness index).

\section{Results and discussion:-}

Summary of mean, minimum and maximum values of hairiness index for four Egyptian cotton genotypes manufactured by combed and combed compact yarns ring spinning process at counts $(\mathrm{Ne})$ 80's and 100's carded are shown in Table 1.

It could be noticed that the hairiness index values occurred in yarns manufactured by the combed ring spinning frame were higher in comparison with yarns that manufactured by the combed compact frame at the same count $(\mathrm{Ne})$ in all studied genotypes. This fact means that combed ring machine produces more hairy yarn than combed compact spinning machine these results are supported by Sheikh, (2000), who reported that the compact yarns are much betters in quality as compared to conventional ring spun yarns and process little hairiness. The compact yarns are characterized by quality parameters such as lower hairiness which are better than those of ring yarns and can be accepted as the number of fibers in the yarn cross section increases and thus presents yarns of high quality. El Mogahzy (2000); Krifa and Ethridge (2003); Krifa and Ethridge (2006) and Strumillo et al. (2007).

For example, mean values of hairiness index for genotype Giza 92 were (2.63 and 3.24) in combed ring yarn while they were (2.24 and 2.64) in combed compact yarn at the two counts being $\mathrm{Ne} 80$ and 100 carded, respectively. With regard to genotype Giza 88, hairiness index averages were 3.91 and 4.44 at $\mathrm{Ne} 80$ 's and 100's, respectively in combed yarn while they were 3.45 and 4.02 in combed compact yarns.

Also, it is appeared that under the two spinning systems, it is assured that combed yarn at Ne 100's have highest hairiness indices compared to yarns that combed at $\mathrm{Ne} 80$ 's in the same genotype. This fact can hold true for all studied cotton genotypes.

However, the comparison of mean values for yarn hairiness index due to machines effects indicated that, the less mean value of hairiness index on the self count (2.24) was obtained from fiber of Giza 92 that manufactured by combed compact spinning frame at $\mathrm{Ne} 80$ 's while the highest mean value of hairiness index (3.91) was obtained from fiber of Giza 88's combed spinning from and count 80's. The less mean value of hairiness index (2.36) was obtained from fiber of Giza 93 that manufactured by combed compact spinning from at Ne 100's while the highest mean value of hairiness index (4.44) was obtained from fiber of Giza 88 that manufactured by combed spinning from at $\mathrm{Ne} 100$ 's. 
Table 1:- Summary of mean, minimum and maximum values of hairiness index for four Egyptian cotton Genotypes manufactured by combed and combed compact yarns ring spinning process at counts (Ne) 80's and 100's carded.

\begin{tabular}{|c|c|c|c|c|c|}
\hline \multirow[t]{2}{*}{ Genotypes } & \multirow[t]{2}{*}{$\begin{array}{l}\text { Descriptive } \\
\text { statistics }\end{array}$} & \multicolumn{2}{|c|}{$\begin{array}{c}\text { Combed yarn ring } \\
\text { Spinning }\end{array}$} & \multicolumn{2}{|c|}{$\begin{array}{c}\text { Combed compact yarn ring } \\
\text { spinning }\end{array}$} \\
\hline & & Ne 80 & Ne 100 & Ne 80 & Ne 100 \\
\hline \multirow{3}{*}{ Giza 92} & Mean & 2.63 & 3.24 & 2.24 & 2.64 \\
\hline & Mini. & 2.20 & 2.90 & 2.00 & 2.10 \\
\hline & Maxi. & 3.10 & 3.90 & 2.60 & 3.50 \\
\hline \multirow[t]{3}{*}{ Giza 88} & Mean & 3.91 & 4.44 & 3.45 & 4.02 \\
\hline & Mini. & 3.60 & 4.10 & 3.00 & 3.70 \\
\hline & Maxi. & 4.20 & 4.90 & 3.90 & 4.30 \\
\hline \multirow[t]{3}{*}{ Giza 93} & Mean & 3.47 & 2.72 & 2.35 & 2.36 \\
\hline & Mini. & 2.20 & 2.40 & 2.00 & 2.20 \\
\hline & Maxi. & 3.90 & 4.10 & 2.80 & 2.90 \\
\hline \multirow{3}{*}{$\begin{array}{c}\text { Giza 84 } \\
(\text { G.70×51B }) \text { s } 62\end{array}$} & Mean & 3.05 & 3.15 & 2.28 & 2.40 \\
\hline & Mini. & 2.40 & 2.70 & 2.00 & 2.20 \\
\hline & Maxi. & 3.50 & 3.80 & 3.00 & 3.60 \\
\hline \multicolumn{6}{|c|}{ H-UT3 hairiness index $=$ Units } \\
\hline
\end{tabular}

\section{Correlation coefficients:-}

For each tested genotype separately, correlation coefficients were computed between each one of fiber properties i.e. fiber length (m.m), fiber strength (g/tex), Micronaire value, short fiber content, elongation (\%) and uniformity index (\%) and UT3 hairiness index spun by combed ring and combed compact systems which produced at Ne 80's and 100 's as shown in Table 2.

The results indicated that, hairiness in yarns at Ne 80's and 100's in combed and combed compact spinning systems correlated negatively and highly significant with fiber length in all genotypes under study. On the other hand, hairiness in yarns at Ne 80's and 100's in combed and combed compact spinning systems correlated positively and highly significant with short fiber content in all genotypes under study. With respect to fiber strength, Micronaire value, elongation and uniformity index, they correlated negatively and highly significant with hairiness index in yarn $\mathrm{Ne} 80$ 's and 100's by using processes combed ring and combed compact ring spinning systems at all genotypes under study.

The data show in Table 2 clearly indicate that there was a upward trend for the short fiber content with increasing of hairiness in $\mathrm{Ne} 80$ 's, 100's combed ring and combed compact yarns at the same count, this positive association between short fiber content and yarn hairiness was confirmed by the highly significant positive correlation coefficients obtained. Conversely, it is rather interesting to note that in all types of yarns and all studied genotypes, the decrease fiber strength are important contributors toward increased yarn hairiness index, so correlation coefficient for fiber length are also high significant but with negative signs, therefore these fibers which measure very long are important contributors toward deceased yarn hairiness index. These finding are in the same line with Zurek et al. (1996); Hequet and Ethridge (2000) and Zhang et al. (2003). 
Table 2:- Correlation coefficients between each one of fiber properties and yarn hairiness index in combed ring and combed compact yarns at counts Ne 80's and 100's in four Egyptian cotton genotypes followed extra long staple category.

\begin{tabular}{|c|c|c|c|c|c|c|c|c|}
\hline \multirow{2}{*}{$\begin{array}{c}\text { Fiber } \\
\text { properties }\end{array}$} & \multicolumn{4}{|c|}{ Combed ring yarns spinning } & \multicolumn{4}{|c|}{ Combed compact yarns ring spinning } \\
\hline & Giza 92 & Giza 88 & Giza 93 & $\begin{array}{c}\text { G. } 84 \\
(\text { G.70×51B }) \mathrm{s} 62\end{array}$ & Giza 92 & Giza 88 & Giza 93 & $\begin{array}{c}\text { G. } 84 \\
(\text { G.70×51B }) \mathrm{s} 62\end{array}$ \\
\hline \multicolumn{9}{|c|}{$\mathrm{Ne} 80 \mathrm{~s}$} \\
\hline FL & $-0.95 * *$ & $-0.96 * *$ & $-0.95 * *$ & $-0.81 * *$ & $-0.69 *$ & $-0.90 * *$ & $-0.94 * *$ & $-0.97 * *$ \\
\hline FS & $-0.96 * *$ & $-0.68^{*}$ & $-0.98 * *$ & $-0.77 * *$ & $-0.81 * *$ & -0.57 & $-0.93 * *$ & $-0.95 * *$ \\
\hline M & $-0.99 * *$ & $-0.96 * *$ & $-0.97 * *$ & $-0.82 * *$ & $-0.76 * *$ & $-90 * *$ & $-0.98 * *$ & $-0.96 * *$ \\
\hline SFC & $0.97 * *$ & $0.89 * *$ & $0.96 * *$ & $0.76 * *$ & $\begin{array}{l}0.77 * * \\
\end{array}$ & $0.98 * *$ & $0.95 * *$ & $0.97 * *$ \\
\hline $\mathbf{E}$ & $-0.98 * *$ & $-0.87 * *$ & $-0.99 * *$ & -0.59 & $-0.76^{* *}$ & $\begin{array}{l}-0.97 * * \\
\end{array}$ & $-0.98 * *$ & $-0.87 * *$ \\
\hline UI & $-0.81 * *$ & $-0.97 * *$ & $-0.97 * *$ & -0.60 & -0.57 & $-0.82 * *$ & $-0.95 * *$ & $-0.89 * *$ \\
\hline \multicolumn{9}{|c|}{$\mathrm{Ne} 100 \mathrm{~s}$} \\
\hline FL & $-0.94 * *$ & $-0.93 * *$ & $-0.96 * *$ & $-0.98 * *$ & $-0.91 * *$ & $-0.90 * *$ & $-0.93 * *$ & $-0.95 * *$ \\
\hline FS & $-0.95 * *$ & $-0.85 * *$ & $-0.99 * *$ & $-0.97 * *$ & $-0.95^{* *}$ & $-0.87 * *$ & $-0.91 * *$ & $-0.98 * *$ \\
\hline $\mathbf{M}$ & $-0.98 * *$ & $-0.92 * *$ & $-0.97 * *$ & $-0.96 * *$ & $-0.96 * *$ & -0.91** & $\begin{array}{l}-0.98 * * \\
\end{array}$ & $-0.94 * *$ \\
\hline SFC & $0.96^{* *}$ & $0.84 * *$ & $0.90 * *$ & $0.93 * *$ & $0.94 * *$ & $0.80 * *$ & $0.97 * *$ & $0.89 * *$ \\
\hline $\mathbf{E}$ & $-0.97 * *$ & $-0.79 * *$ & $-0.97 * *$ & $-0.88 * *$ & $-0.97 * *$ & $-0.79 * *$ & $-0.96 * *$ & $-0.98 * *$ \\
\hline UI & $-0.79 * *$ & $-0.95 * *$ & $-0.92 * *$ & $-0.82 * *$ & $-0.74 * *$ & $-0.93 * *$ & $\begin{array}{l}-0.98 * * \\
\end{array}$ & -0.85 ** \\
\hline
\end{tabular}

Abbreviations: FL: fiber length, FS: fiber strength, M: micronaire reading, SFC: short fiber content, E: elongation and UI: uniformity index.

* and **: Significant and highly significant.

\section{Full Model regression:-}

The results of multiple linear regression analysis of yarn hairiness as dependent variable and six fiber properties as explanatory variables (fiber length, fiber strength, micronaire, short fiber content, fiber elongation and uniformity index) under combed ring and combed compact ring spinning systems at count 80's of cotton genotypes are presented in Table 3.

The results revealed that the supposed multiple regression models were significantly explained the most variability of yarn hairiness of cotton genotypes.

Statistically, goodness of fit was satisfied for the six supposed models where the coefficient of determination $\left(\mathrm{R}^{2}\right)$ ranged from $87.4 \%$ to $99.0 \%$ indicating that the most yarn hairiness variation was attributed to the tested fiber properties. The residuals content $\left(1-\mathrm{R}^{2} \%\right)$ may be returned to some errors during measuring the fiber and yarn hairiness, some fiber properties were not take into account under the current investigation and/or unknown variation (random error).

On the other hand, the values of adjusted $\mathrm{R}^{2}$ were very close to their corresponding $\mathrm{R}^{2}$ values giving evidence on the goodness of fit for the supposed models. Similar trend of results was obtained by Fares et al. (2010). 
Table 3:- Full model regression analysis to predict yarn hairiness using six fiber properties of four Egyptian cotton genotypes under combed, and combed compact yarns ring spinning at count 80's.

\begin{tabular}{|c|c|c|c|c|c|c|c|c|c|}
\hline \multirow[t]{2}{*}{ Genotypes } & \multicolumn{7}{|c|}{ Partial regression coefficients } & \multirow[t]{2}{*}{$\mathbf{R}^{2} \%$} & \multirow{2}{*}{$\begin{array}{l}\text { Adj. } \\
\mathbf{R}^{2} \%\end{array}$} \\
\hline & Constant & FL & FS & M & SFC & $\mathbf{E}$ & UI & & \\
\hline \multicolumn{10}{|c|}{ Combed yarns ring spinning } \\
\hline Giza 92 & -17.1 & 0.200 & -0.093 & 0.320 & 0.34 & 0.035 & 0.161 & 97.5 & 92.6 \\
\hline Giza 88 & -31.8 & 0.340 & 0.337 & 0.376 & 0.020 & 0.769 & 0.107 & 99.0 & 98.8 \\
\hline Giza 93 & -6.3 & -0.005 & -0.036 & 0.001 & 1.44 & -0.144 & 0.073 & 98.4 & 96.3 \\
\hline $\begin{array}{c}\text { G. } 84 \\
(\text { G.70×51B }) \text { s62 }\end{array}$ & 82.6 & -0.948 & -0.483 & -0.140 & 0.799 & 0.150 & -0.350 & 87.4 & 62.2 \\
\hline \multicolumn{10}{|c|}{ Combed compact yarns ring spinning } \\
\hline Giza 92 & -50.7 & 0.21 & 0.235 & -0.93 & -0.002 & 0.128 & 0.418 & 91.5 & 74.5 \\
\hline Giza 88 & 12.0 & -0.055 & -0.105 & -0.255 & 0.059 & -0.031 & -0.010 & 98.1 & 92.0 \\
\hline Giza 93 & 2.20 & 0.310 & 0.005 & 0.010 & -0.236 & -0.076 & -0.116 & 94.7 & 88.2 \\
\hline $\begin{array}{c}\text { G. } 84 \\
(\text { G.70×51B)s62 }\end{array}$ & 12.40 & -0.069 & 0.072 & -0.297 & 0.079 & -0.096 & -0.026 & 90.0 & 81.0 \\
\hline
\end{tabular}

Abbreviations: FL: fiber length, FS: fiber strength, M: micronaire reading, SFC: short fiber content, E: elongation and UI: uniformity index.

On the other hand, the results of full model regression under combed ring and combed compact ring spinning systems at count 100's were shown in Table 4. All postulated regression models were significant and reflected the most variation of the yarn hairiness expressed as high values of the $\mathrm{R}^{2}$ ranged from 95.0 to 99.0 the previous results proved the validity of the supposed models of regression, in addition, the clear closeness between $R^{2}$ values and their corresponding a adjusted $\mathrm{R}^{2}$ values gave another evidence. Accordingly, the present regression equations would be accurately applied to predict the yarn hairiness using fiber traits. The current results are in harmony with El-Hariry et al. (1990), Sawires et al. (1990) and Fares et al. (2010).

Table 4:- Full model regression analysis to predict yarn hairiness using six fiber properties of four Egyptian cotton genotypes under combed, and combed compact yarns ring spinning at count 100's.

\begin{tabular}{|c|c|c|c|c|c|c|c|c|c|}
\hline \multirow[t]{2}{*}{ Genotypes } & \multicolumn{7}{|c|}{ Partial regression coefficients } & \multirow[t]{2}{*}{$\mathbf{R}^{2} \%$} & \multirow{2}{*}{$\begin{array}{l}\text { Adj. } \\
\mathbf{R}^{2} \%\end{array}$} \\
\hline & Constant & FL & FS & M & SFC & $\mathbf{E}$ & UI & & \\
\hline \multicolumn{10}{|c|}{ Combed yarns ring spinning } \\
\hline Giza 92 & 30.0 & 0.006 & -0.253 & -0.265 & -0.281 & -0.238 & -0.118 & 95.0 & 91.0 \\
\hline Giza 88 & 26.3 & -0.164 & -0.030 & -0.683 & -0.016 & 0.056 & -0.141 & 98.8 & 96.5 \\
\hline Giza 93 & -55.9 & 1.55 & 0.001 & -0.139 & -0.36 & 0.007 & 0.113 & 96.4 & 91.8 \\
\hline $\begin{array}{c}\text { G. } 84 \\
(\text { G.70×51B }) \mathrm{s} 62\end{array}$ & 23.2 & -0.178 & -0.117 & -0.004 & 0.046 & -0.382 & -0.070 & 97.6 & 92.7 \\
\hline \multicolumn{10}{|c|}{ Combed compact yarns ring spinning } \\
\hline Giza 92 & -42.2 & 0.474 & -0.146 & -0.001 & 0.135 & 0.395 & 0.396 & 99.0 & 97.4 \\
\hline Giza 88 & 3.1 & 0.248 & 0.260 & 0.198 & -0.050 & -0.117 & -0.105 & 96.5 & 85.8 \\
\hline Giza 93 & -6.3 & 0.262 & -0.058 & 0.002 & 0.673 & 0.117 & -0.025 & 98.0 & 95.6 \\
\hline $\begin{array}{c}\text { G. } 84 \\
(\text { G.70×51B)s62 }\end{array}$ & $\begin{array}{l}-10.3 \\
\end{array}$ & 0.083 & -0.050 & -0.808 & 0.209 & 0.671 & 0.104 & 98.0 & 96.3 \\
\hline
\end{tabular}

Abbreviations: FL: fiber length, FS: fiber strength, M: micronaire reading, SFC: short fiber content,

E: elongation and UI: uniformity index.

\section{Stepwise multiple linear regression model:-}

Stepwise regression procedure has been applied to determine the most effective independent variables which make the maximum contributions to the coefficient of determination $\left(R^{2}\right)$ as described by Draper and Smith (1966).

Tables 5 and 6 contained the prediction equations and coefficients of determination $\left(\mathrm{R}^{2}\right)$ of the best model and rank of contributors (fiber properties) to yarn hairiness index obtained for each genotype separately manufactured by combed yarn ring and combed compact spinning frame at count $(\mathrm{Ne}) 80$ 's and100's. It could be seen that the order and amount of fiber parameters that affecting the yarn hairiness index differed from one genotype to another. 
Moreover in the same genotype, the order and relative contribution of six fiber parameters differed according to processes of yarn.

Table 5 showed the rank of the best contributors and regression equations that defines relationship between hairiness index in combed ring and combed compact spinning at Ne 80's and six fiber properties of interest within each one of tested genotypes. Regarding genotype Giza 92, the best contributor to hairiness index in combed ring yarn at Ne 80's was short fiber content with $\mathrm{R}^{2}=94 \%$, and in the $2^{\text {nd }}$ step the maximum contributors were short fiber content and uniformity with $\mathrm{R}^{2}=96 \%$ while in the $3^{\text {rd }}$ step the maximum contributors were short fiber content, uniformity index and fiber length with an $\mathrm{R}^{2}=97 \%$. It could be noticed that in the final regression step, the best contributor to hairiness index in combed compact ring yarns at Ne 80's were fiber strength, Micronaire value, Elongation and uniformity index $\left(\mathrm{R}^{2}=90 \%\right)$.

Concerning Giza 88, using combed ring at Ne 80's, all tested fiber properties except short fiber content were the best contributor to yarn hairiness index $\left(\mathrm{R}^{2}=98 \%\right)$ while under combed compact ring yarns the most effective fiber properties to yarn hairiness index were elongation and micronaire reading with $R^{2}=97 \%$ ).

Considering genotype Giza 93, only two fiber properties being short fiber content and elongation were the most contributors to yarn hairiness index $\left(\mathrm{R}^{2}=96 \%\right)$ using combed ring while elongation and uniformity index were the most important fiber properties recording $\mathrm{R}^{2}=94 \%$.

Fiber length, fiber strength and short fiber content were the best contributors to hairiness index in combed ring yarn using the fibers of genotype Giza $84(\mathrm{G} .70 \times 51 \mathrm{~B}) \mathrm{s} 62$ with $\mathrm{R}^{2}=79 \%$ but when the fibers spun using combed compact ring, the most effective fiber properties were micronaire reading and short fiber content recording $\mathrm{R}^{2}=85 \%$.

Table 6 showed the rank of the best regression equations that defines the associations between hairiness index in combed ring and combed compact spinning at Ne 100's and six fiber properties of interest within each one of tested genotypes. Regarding genotype Giza 92, the best contributor to hairiness index in combed ring yarn at Ne 100's was elongation with an $\mathrm{R}^{2}=85 \%$, and in the $2^{\text {nd }}$ step the maximum contributors were elongation and fiber strength with $\mathrm{R}^{2}=92 \%$. It could be noticed that in the final regression step, the best contributors to hairiness index in combed compact ring yarns at Ne 100's were fiber length and uniformity index $\left(\mathrm{R}^{2}=98 \%\right)$.

Concerning Giza 88, using combed ring at $\mathrm{Ne} 100$ 's, uniformity index and micronaire reading were the best contributors to yarn hairiness index $\left(\mathrm{R}^{2}=98 \%\right)$ while under combed compact ring yarns the most effective fiber properties to yarn hairiness index were fiber length and fiber strength with $R^{2}=96 \%$ ).

Considering genotype Giza 93, three fiber properties being uniformity index, fiber strength and fiber length were the most contributors to yarn hairiness index $\left(\mathrm{R}^{2}=96 \%\right)$ using combed ring and combed compact spinning at Ne 100 's.

Fiber length, fiber strength and elongation were the best contributors to hairiness index in combed ring yarn using the fibers of genotype Giza 84 (G.70×51B)s 62 with $\mathrm{R}^{2}=96 \%$ but when the fibers spun using combed compact ring, the most effective fiber properties were micronaire reading, short fiber content and elongation recording $\mathrm{R}^{2}=97 \%$. Similar results were obtained by Zurek et al. (1996), Zhang et al. (2003) and Altas and Kadoglu (2006). All stepwise regression models were significant and reflected the most variation of the yarn hairiness expressed as high values of the $\mathrm{R}^{2}$. The previous results proved the validity of the supposed models. In addition, the clear closeness between $\mathrm{R}^{2}$ values and their corresponding adjusted $\mathrm{R}^{2}$ values gave another evidence of validity. 
Table 5:- Regression equations and the coefficients of determination $\left(\mathrm{R}_{2}\right)$ for the best variables within each four Egyptian Cotton Genotypes for hairiness in combed and combed compact Yarns Ring spinning at count 80's

\begin{tabular}{|c|c|c|c|c|c|c|c|c|}
\hline \multirow[t]{2}{*}{ Genotypes } & \multicolumn{4}{|c|}{$\begin{array}{c}\text { Combed Compact Yarns Ring Spinning at } \\
\text { Count 80's }\end{array}$} & \multicolumn{4}{|c|}{$\begin{array}{c}\text { Combed Yarns Ring Spinning at } \\
\text { Count 80's }\end{array}$} \\
\hline & Rank & Equation & $\begin{array}{l}\mathbf{R}^{2} \\
\%\end{array}$ & $\begin{array}{l}\text { Adj. } \\
\mathbf{R}^{2} \%\end{array}$ & Rank & Equation & $\mathbf{R}^{2} \%$ & $\begin{array}{l}\text { Adj. } \\
\mathbf{R}^{2} \%\end{array}$ \\
\hline Giza92 & $\begin{array}{r}\mathbf{X}_{4} \\
\mathbf{X}_{4} \mathbf{X}_{6} \\
\mathbf{X}_{4} \mathbf{X}_{6} \mathbf{X}_{1}\end{array}$ & 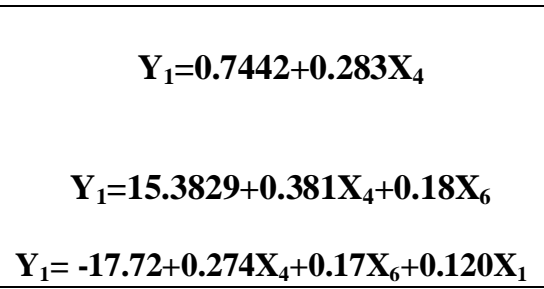 & $\begin{array}{l}94 \\
96 \\
97\end{array}$ & $\begin{array}{l}90 \\
94 \\
95\end{array}$ & $\begin{array}{l}\mathbf{X}_{3} \mathbf{X}_{5} \\
\mathbf{X}_{6} \\
\mathbf{X}_{2} \mathbf{X}_{3} \\
\mathbf{X}_{5} \mathbf{X}_{6}\end{array}$ & 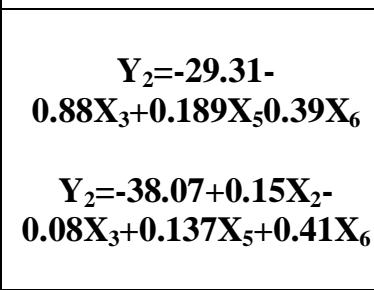 & $\begin{array}{l}89 \\
90\end{array}$ & $\begin{array}{l}84 \\
82\end{array}$ \\
\hline Giza88 & $\begin{array}{c}\mathbf{X}_{1} \mathbf{X}_{2} \\
\mathbf{X}_{5} \mathbf{X}_{6} \\
\\
\\
\mathbf{X}_{1} \mathbf{X}_{2} \\
\mathbf{X}_{3} \mathbf{X}_{5} \mathbf{X}_{6}\end{array}$ & $\begin{array}{c}Y_{1}=21.77+0.199 X_{1}+0.233 X_{2^{-}} \\
0.599 X_{5}+0.130 X_{6} \\
Y_{1}=-28.84+0.36 X_{1}+0.331 X_{2}+0.33 X_{3^{-}} \\
0.754 X_{5}+0.083 X_{6}\end{array}$ & 98 & 95 & $X_{5} X_{3}$ & $\begin{array}{c}Y_{2}=6.153-0.447 X_{5} \\
\\
Y_{2}=\begin{array}{c}\text { 6.044- } 0.232 \\
0.314 X_{3}\end{array}\end{array}$ & 97 & 92 \\
\hline Giza93 & $\begin{array}{c}\mathbf{X}_{4} \\
\mathbf{X}_{4} \mathbf{X}_{5}\end{array}$ & $\begin{array}{c}Y_{1}=-3.985+1.74 X_{4} \\
Y 1=0.4264+0.96 X_{4}-0.178 X_{5}\end{array}$ & 95 & $\begin{array}{l}94 \\
95\end{array}$ & $\begin{array}{c}\mathbf{X}_{6} \\
\mathbf{X}_{6} \mathbf{X}_{5}\end{array}$ & $\begin{array}{c}Y_{2}=18.40-0.185 X_{6} \\
Y_{2}=\underset{15.85-0.151 X_{6}-}{0.070 X_{5}}\end{array}$ & $\begin{array}{r}93 \\
94\end{array}$ & $\begin{array}{l}92 \\
90\end{array}$ \\
\hline $\begin{array}{c}\text { G. 84 } \\
(\mathbf{G 7 0 \times 5 1 B}) \\
\text { s62 }\end{array}$ & $\begin{array}{c}\mathbf{X}_{2} \\
\mathbf{X}_{1} \mathbf{X}_{2} \\
\mathbf{X}_{1} \mathbf{X}_{2} \\
\mathbf{X}_{4}\end{array}$ & $\begin{array}{c}Y_{1}=15.63-0.291 X_{2} \\
Y_{1}=32.43-0.17 X_{1}-0.522 X_{2} \\
Y_{1}=34.80-0.36 X_{1}-0.473 X_{2}+0.32 X_{4}\end{array}$ & $\begin{array}{l}71 \\
79\end{array}$ & $\begin{array}{l}61 \\
63 \\
69\end{array}$ & $\begin{array}{c}\mathbf{X}_{3} \\
\mathbf{X}_{3} \mathbf{X}_{4}\end{array}$ & $\begin{array}{c}Y_{2}=5.358-0.578 X_{3} \\
\\
Y_{2}=4.165- \\
0.420 X_{3}+0.076 X_{4}\end{array}$ & $\begin{array}{l}82 \\
85\end{array}$ & 73 \\
\hline
\end{tabular}

$\left(Y_{1}\right)$ Hairiness in Combed Yarns Ring Spinning at count 80's, $\left(Y_{2}\right)$ Hairiness in Combed Compact Yarns Ring Spinning at count 80's

$\left(\mathrm{x}_{1}\right)$ Fiber Length $(\mathrm{m} . \mathrm{m}),\left(\mathrm{x}_{2}\right)$ Fiber strength $(\mathrm{g} / \mathrm{tex}),\left(\mathrm{x}_{3}\right)$ Micronaire, $\left(\mathrm{x}_{4}\right)$ short Fiber Content, $\left(\mathrm{x}_{5}\right)$ Elongation $(\%),\left(\mathbf{x}_{6}\right)$ Uniformity $(\%)$ 
Table 6:- Regression equations and the coefficients of determination $\left(\mathrm{R}_{2}\right)$ for the best variables within each four Egyptian Cotton Genotypes for hairiness in combed and combed compact Yarns Ring spinning at count 100's

\begin{tabular}{|c|c|c|c|c|c|c|c|c|}
\hline \multirow[t]{2}{*}{ Genotypes } & \multicolumn{4}{|c|}{$\begin{array}{l}\text { Combed Yarns Ring Spinning at } \\
\text { Count 100's }\end{array}$} & \multicolumn{4}{|c|}{$\begin{array}{c}\text { Combed Compact Yarns Ring Spinning at } \\
\text { Count 100's }\end{array}$} \\
\hline & Rank & Equation & $\mathrm{R}^{2} \%$ & $\underset{\%}{\operatorname{Adj} . R^{2}}$ & Rank & Equation & $\mathbf{R}^{2} \%$ & $\begin{array}{l}\text { Adj } \\
\mathbf{R}^{2} \%\end{array}$ \\
\hline Giza92 & $\begin{array}{c}\mathbf{X}_{5} \\
\mathbf{X}_{5} \mathbf{X}_{2}\end{array}$ & $\begin{array}{c}Y_{3}=6.104-0.470 X_{5} \\
Y_{3}=14.229-0.261 X_{5^{-}} \\
0.192 X_{2}\end{array}$ & $\begin{array}{l}85 \\
92 \\
\end{array}$ & $\begin{array}{r}80 \\
90 \\
\end{array}$ & $\begin{array}{c}\mathbf{X}_{1} \\
\mathbf{X}_{1} \mathbf{X}_{6} \\
\end{array}$ & $\begin{array}{c}Y_{4}=-15.32+0.518 X_{1} \\
Y_{4}=- \\
47.78+0.700 X_{1}+0.301 X_{6}\end{array}$ & $\begin{array}{l}95 \\
98 \\
\end{array}$ & 97 \\
\hline Giza88 & $\begin{array}{c}\mathbf{X}_{6} \\
\mathbf{X}_{6} \mathbf{X}_{3}\end{array}$ & $\begin{array}{c}Y 3=36.62-0.377 X_{6} \\
Y_{3}=25.13-0.234 X_{6}-0.20 X_{3}\end{array}$ & 97 & 93 & $\begin{array}{c}\mathbf{X}_{1} \\
\mathbf{X}_{1} \mathbf{X}_{2}\end{array}$ & $\begin{array}{c}Y_{4}=-3.638+0.2095 X_{1} \\
Y_{4}=1.972+0.1284 X_{1}- \\
0.055 X_{2}\end{array}$ & $\begin{array}{l}95 \\
96\end{array}$ & $\begin{array}{l}92 \\
95\end{array}$ \\
\hline Giza93 & $\begin{array}{c}\mathbf{X}_{6} \\
\mathbf{X}_{1} \mathbf{X}_{2} \\
\mathbf{X}_{1} \mathbf{X}_{2} \\
\mathbf{X}_{6}\end{array}$ & $\begin{array}{c}Y_{3}=26.68-0.276 X_{6} \\
Y_{3}=-22.24- \\
0.126 X_{2}+0.84 X_{1} \\
\\
Y_{3}=-37.57+0.067 X_{6}- \\
0.137 X_{2}+1.11 X_{1}\end{array}$ & $\begin{array}{l}86 \\
95 \\
96\end{array}$ & $\begin{array}{l}84 \\
94 \\
94\end{array}$ & $\begin{array}{c}\mathbf{X}_{6} \\
\mathbf{X}_{2} \mathbf{X}_{6} \\
\\
\mathbf{X}_{1} \mathbf{X}_{2} \\
\mathbf{X}_{6}\end{array}$ & $\begin{array}{c}Y_{4}=14.548-0.141 X_{6} \\
Y_{4}=13.415-0.106 X_{6}- \\
\quad 0.041 X_{2} \\
\\
Y_{4}=-9.910-0.009 X_{6^{-}} \\
0.053 X_{2}+0.42 X_{1}\end{array}$ & $\begin{array}{l}90 \\
94\end{array}$ & $\begin{array}{l}89 \\
93\end{array}$ \\
\hline $\begin{array}{c}\text { G. } 84 \\
(\text { G. } 70 \times 51 B) \\
\text { s62 }\end{array}$ & $\begin{array}{c}\mathbf{X}_{5} \\
\mathbf{X}_{2} \mathbf{X}_{5} \\
\\
\mathbf{X}_{1} \mathbf{X}_{2} \\
\mathbf{X}_{5}\end{array}$ & $\begin{array}{c}Y_{3}=5.388-0.347 X_{5} \\
Y_{3}=-0.077 X_{2}-0.231 X_{5} \\
\\
Y_{3}=13.123-0.066 X_{1^{-}} \\
0.122 X_{2}-0.309 X_{5}\end{array}$ & $\begin{array}{l}93 \\
95\end{array}$ & $\begin{array}{l}90 \\
94\end{array}$ & $\begin{array}{c}\mathbf{X}_{3} \\
\\
\mathbf{X}_{3} \mathbf{X}_{4} \\
\mathbf{X}_{3} \mathbf{X}_{4} \\
\mathbf{X}_{5}\end{array}$ & $\begin{array}{c}Y_{4}=4.503-0.527 X_{3} \\
Y_{4}=3.457- \\
0.388 X_{3}+0.067 X_{4} \\
Y_{4}=1.937- \\
0_{3.512 X_{3}+0.138 X_{4}+0.22} \\
X_{5}\end{array}$ & $\begin{array}{l}94 \\
96\end{array}$ & $\begin{array}{l}90 \\
91\end{array}$ \\
\hline
\end{tabular}

$\left(\mathrm{Y}_{3}\right)$ Hairiness in Combed Yarns Ring Spinning at count 100's, $\left(\mathrm{Y}_{4}\right)$ Hairiness in Combed Compact Yarns Ring Spinning at count 100 's

$\left(\mathrm{x}_{1}\right)$ Fiber Length $(\mathrm{m} . \mathrm{m}),\left(\mathrm{x}_{2}\right)$ Fiber strength $(\mathrm{g} /$ tex $),\left(\mathrm{x}_{3}\right)$ Micronaire, $\left(\mathrm{x}_{4}\right)$ short Fiber Content, $\left(\mathrm{x}_{5}\right)$ Elongation $(\%),\left(\mathbf{x}_{6}\right)$ Uniformity $(\%)$

\section{References:-}

1. Altaş, S. and H. Kadoğlu, 2006. Determining fiber properties and linear density effect on cotton yarn hairiness in ring spinning. Fibers and Textile in Eastern Europe July / September, 14 (3): 48-51.

2. Artzt, P., 2000. The special structure of compact yarns- advantages in downstream processing. Proc. Cotton Conference 1:798-803, National Cotton Council, Memphis, TN.

3. ASTM, 1998. American society for testing and materials. designation, (D- 1578-67), (D- 1425-81), (D- 460386), (D-4604-86), (D- 4605-86), (D-1425-98). Philadelphia 3, Pa, U.S.A.

4. Draper, N. R. and H. Smith, 1966. Applied Regression Analysis, 407pp. John Wiley and Sons, Inc, New York.

5. El Mogahzy, Y. E., 2000. How the machine maker deals with the issue of short fiber content (ANITMA 99 perspective). Proc. Cotton Conference 2:1503-1507 (2000), National Cotton Council, Memphis, TN.

6. Fares, W. M., S. K. A. Islam, KH. M. M. Hussein and A. A. Hassan, 2010. An application of modern statistical approach to estimate a technological value of same Egyptian cotton Varieties. The sixth Inter. Conf. of Sustain Agric. and Develop. 27-29, December, 43-56. 
7. Hequet, E. 1999. Application of the AFIS Multidata. Proc. Cotton Conference 1:666-670. National Cotton Council, Memphis, TN.

8. Hequet, E. and M. D. Ethridge, 2000. Effect of cotton fiber length distribution on yarn quality. Proc. Cotton Conference 2:1507-1514. National Cotton Council, Memphis, TN.

9. Karapinar, B. O. and N. Erdem, 2003. Comparison of quality characteristics of yarns spun from Aegean Cotton Fibers and their mixtures with South-East Anatolian Cotton Fibers. Fibers \& Textiles in Eastern Europe. 11(4): 26-28.

10. Krifa, M. and D. Ethridge, 2003. Compact ring spun yarns: an examination of some productivity issues. Textile Topics, 2: 2-8.

11. Krifa, M. and D. Ethridge, 2006.Compact spinning effect on cotton yarn quality: Interactions with Fiber Characteristics. Textile Research Journal (TRJ), 76(5): 388-399.

12. Sağbaş, A. and R. Erol, 2004. Process optimization of yarn hairiness, yarn strength and cost for staple-yarn. YA/EM'2004 - Yöneylem Araştırması /Endüstri Mühendisliği - Proc. Ulusal Kongresi, 15-18 Haziran 2004 Gaziantep - Adana.

13. SDL 089, 1994. Micromat Tester Instruction Manual. Shirley Developments Limited, Stockport, England.

14. Sheikh, H.R., 2000. Recent developments of ring spinning frames. Pakistan Text. J. 49: 26-30.

15. Strumilło, L. J.; D. Cyniak; J. Czekalski, and T. Jackowski, 2007. Quality of cotton yarns spun using ring-, compact-, and rotor-spinning machines as a function of selected spinning process parameters. Fibers \& Textiles in Eastern Europe January / March 2007, 15, No. 1 (60): 24-30.

16. Zhang, Y.; C. Kyle Shofner; and F. M. Shofner, 2003. True short fiber content: complete fiber length distributions from tapered beards. Proc. Cotton Conferences, Nashville, Tennessee, PP. 1967- 1977.

17. Zurek, W.; M. Grenta; I.Frydrych; and G. Balcar, 1996. The use of AFIS for estimation of cotton fiber

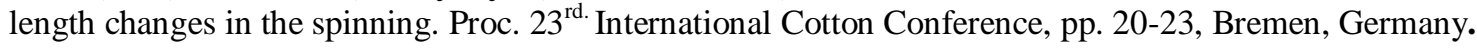

